\title{
Social Work's Program By Universitas Negeri Malang Spraying Desinfectant of Distribution of Covid-19 Trafficking Kunti District, Bungkal Ponorogo
}

\section{Hikmah Fatimah, Ulinnuha Mastuti Hafsah}

Universitas Negeri Malang

(corresponding author)*

Hikmahfatimah2@gmail.com

\begin{abstract}
Corona virus pandemic or Covid-19 that occurs in all countries in the world causes a decrease in various sectors in life. In a long period of time, no vaccine has been found to prevent transmission of the virus. This has inspired the Covid edition of social works program at Universitas Negeri Malang (State University of Malang) to make a breakthrough in preventing Covid-19 transmission. One of the work programs that showed a breakthrough in preventing Covid-19 transmission was spraying disinfectants in Kunti Village, Bungkal District, Ponorogo.Spraying of disinfectants is carried out $5 x$ within a period of 45 days by using an electric sprayer with disinfectants and water solvents. Spraying disinfectants is expected to kill the virus that is developing in the body of bacteria that will die if exposed to disinfectants, so as to reduce the amount of ODP in the village of Kunti
\end{abstract}

Keywords: Corona Virus, patients, Disinfecting Spraying

\section{INTRODUCTION}

In 2020, the wheels of world activity will stop as a result of a pandemic caused by the corona virus. Corona virus is one type of virus with a single strain of positive RNA, encapsulated and not segmented(Hogue \& Machamer, 2014). The corona virus has a cube-like structure and is supplemented by an $\mathrm{S}$ protein located on the surface of the virus. $\mathrm{S}$ protein plays a role in attaching and introducing viral RNA to host cells or host cells(Yuliana, 2020). Corona virus has 120-160 nm with a diameter of 65-125 nm. Subgroups of the family coronavirus are alpha (a), beta (b), gamma (c) and delta (d) coronavirus. Initially, the corona virus only infects bats and is then eaten by intermediary animals such as camels, ferrets, snakes and anteaters(Ali et al., 2020). But the corona virus also infects humans, this is due to animals that have been infected with the corona virus consumed by humans(Khan et al., 2020). In the human body corona virus causes acute lung injury (ALI) and acute respiratory distress syndrome (ARDS) which causes lung failure so that it can result in death(Shereen et al., 2020). Corona virus causes Covid-19 disease. The corona virus is known to originate from Wuhan, China. Because it spreads by human transmission or through droplets that come out when coughing or sneezing(Ong et al., 2020) Corona virus can spread very quickly, causing many casualties(Kumar, 2020). In addition to droplets, the corona virus also spreads through the surface of objects 
such as door handles, toilet seats, light switches, windows, cabinets, and ventilation fans.(Van Doremalen et al., 2020). All countries in the world are affected by the corona virus pandemic. Various sectors in the world experienced a sharp decline. Until now there has not been found drugs or vaccines that can reduce the number of victims due to the Covid-19 pandemic. The vaccine can help memory $\mathrm{T}$ cells to recognize the Corona virus. If the body is infected with a virus, the attack can be stopped more quickly because the memory B cells have stored information about the virus and then activate the production of antibody molecules(Fatmah, 2006).

Because a vaccine for Covid19 has not been found yet, Covid UM's Community Service Program is providing innovation services in the form of preventing corona virus transmission by spraying disinfectants in Kunti village, Bungkal District, Ponorogo Regency. Disinfecting spraying aims to prevent transmission of the corona virus so that it can suppress the number of Insiders in Monitoring (ODP) in the village of Kunti(RI Ministry of Health, 2020). On June 6, 2020 there were 21 ODPs recorded. The disinfecting spraying activity is a necessity in the village of Kunti to remember that there is a PDP that can be a positive corona virus patient at any time.(RI Ministry of Health, 2020). Spraying activities really need to be done to reduce transmission(Dellanno et al., 2009). Viruses and bacteria will die if they come into contact with disinfectants that contain a number of chemicals that can cause damage to the bacterial cell membrane and deactivate viruses, such as Clorin $(\mathrm{Cl})($ Yuliana, 2020). Corona virus is very sensitive to heat and chemicals. The corona virus becomes inactive when interacting with disinfectants containing chlorine, lipid solvents at a temperature of $56^{\circ} \mathrm{C}$ for 30 minutes, ether, alcohol, perioxysiacetic acid, non-ionic detergent, and formalin. However, Chlorhexinin is not effective in deactivating the virus(Wang et al., 2020). Disinfectants that can activate the virus can be Ethanol (78\% -95\%), iso-propanol (70\%-100\%), a combination of $45 \%$ isopropanol with $30 \%$ n-propanol, glutardialdehyde (0.5-2.5\%), formaldehyde $(0.7 \%-1 \%)$ and povidone iodine $(0.23 \%-7.5 \%)$ can very easily deactivate the corona virus with $4 \log 10$ infectivity. Sodium hypochlorite works effectively with a concentration of at least $0.21 \%$. Hydrogen peroxide is effective at a concentration of $0.5 \%$ with a exposure time of 1 minute(Kampf, 2020).

\section{METHOD}

Disinfecting spraying is done by using an electric sprayer. The disinfectants used are Accelerated hydrogen peroxide $0.5 \%$, Benzalkonium chloride $0.05 \%$, Chloroxylenol $0.12 \%$, Ethyl alcohol $62-71 \%$, Iodine in iodophor $50 \mathrm{ppm}$, Isopropanol 50\%, Pine oil $0.23 \%$, Povidone -iodine 1\%, Sodium hypochlorite $0.05-0.5 \%$, Sodium chlorite $0.23 \%$, and Sodium dischloroisocyanurate $0.1-0.5 \%$ which have been dissolved using water. Disinfecting spraying was carried out in all houses in Kunti village which included 4 RT. Spraying is done outside and inside the residents' homes.

\section{Results and Discussion}

Community service activities through the disinfecting spraying program have been successfully implemented. The disinfectant used contains $0.5 \%$ Accelerated hydrogen peroxide, Benzalkonium chloride 0.05\%, Chloroxylenol 0.12\%, Ethyl alcohol 62-71\%, Iodine in iodophor $50 \mathrm{ppm}$, Isopropanol 50\%, Pine oil 0.23\%, Povidone -iodine 1\%, Sodium hypochlorite 0.05-0.5\%, Sodium chlorite $0.23 \%$, and Sodium dischloroisocyanurate $0.1-0.5 \%$. It is known that this material can kill bacteria and deactivate viruses. Disinfectants work by damaging bacterial cell walls and destroying enzymes that viruses use to multiply.

Spraying activity begins with dissolving disinfectant with water, followed by spraying in the field. Spraying activities carried out throughout the village area of Kunti which includes 4 RT. The activity was participated by villagers and KKN students. Disinfecting spraying is done 5 times in a period of 45 days. The first spraying activity was carried out in RT 01 , the second spraying was in RT 02, the third spraying was in RT 03, the fourth spraying was in RT 04, and 
the fifth spraying was focused in the Kunti village hall. Spraying is done outside and inside the homes of villagers. The obstacle faced is the presence of residents who are still outside the house so spraying can only be done outside the house because the house is locked. The impact is that there are some areas in the village of Kunti that are not reached by spraying disinfection. Efforts are being made to reduce the area that has not been reached by spraying is carried out spraying in the homes of residents who have not been sprayed at the next spraying activity (following). From the ODP data before and after spraying disinfectants, a decrease is known. Before spraying disinfectants on June 6, 2020 there were 21 residents who became ODP. But after 5 times of spraying in a period of 45 days the amount of ODP decreased to 1 person. This shows that disinfection spraying and self-isolation at home are very effective in preventing the spread of corona virus. Efforts are being made to reduce areas not covered by spraying by spraying at residents' homes that have not been sprayed at the next spraying activity (following). From the ODP data before and after spraying disinfectants, a decrease is known. Before spraying disinfectants on June 6, 2020 there were 21 residents who became ODP. But after 5 times of spraying within a period of 45 days the amount of ODP decreased to 1 person. This shows that disinfection spraying and self-isolation at home are very effective in preventing the spread of corona virus. Efforts are being made to reduce the area that has not been reached by spraying is carried out spraying in the homes of residents who have not been sprayed at the next spraying activity (following). From the ODP data before and after spraying disinfectants, a decrease is known. Before spraying disinfectants on June 6, 2020 there were 21 residents who became ODP.

But after 5 times of spraying in a period of 45 days the amount of ODP decreased to 1 person. This shows that disinfection spraying and self-isolation at home are very effective in preventing the spread of corona virus. Before spraying disinfectants on June 6, 2020 there were 21 residents who became ODP. But after 5 times of spraying in a period of 45 days the amount of ODP decreased to 1 person. This shows that disinfection spraying and self-isolation at home are very effective in preventing the spread of corona virus. Before spraying disinfectants on June 6, 2020 there were 21 residents who became ODP. But after 5 times of spraying in a period of 45 days the amount of ODP decreased to 1 person. This shows that disinfection spraying and selfisolation at home are very effective in preventing the spread of corona virus.

\section{TABLE, GRAPH AND PICTURE}

Table 1. The amount of ODP reduction after spraying

\begin{tabular}{|l|r|r|r|r|r|}
\hline \multirow{2}{*}{} & \multicolumn{5}{|c|}{ Spraying Into } \\
\cline { 2 - 6 } & 1 & 2 & 3 & 4 & 5 \\
\hline ODP & 21 & 15 & 7 & 4 & 1 \\
\hline
\end{tabular}

Source: Author's personal data

It is known that in the village of Kunti before spraying there were 21 residents with ODP status. After spraying disinfectants for $5 \mathrm{x}$ and applying self-isolation at home, it shows a decrease in the number of people who have ODP status to 1 person. This shows that disinfecting spraying needs to be done as an effort to prevent corona virus transmission. 


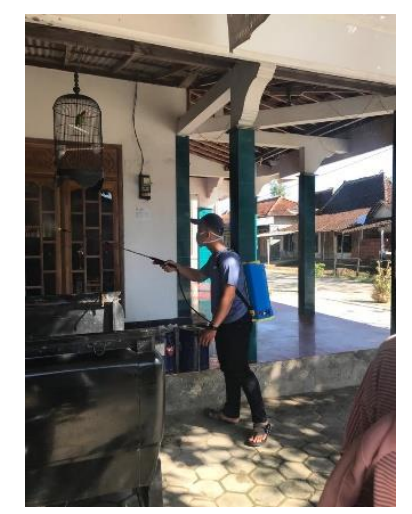

Source: author's personal document

Figure 1. RT 01 Spraying Activity

The picture above is a documentary of disinfecting spraying done by KKN UM in Kunti village on RT 01 . Disinfecting spraying is done outside and inside the house.

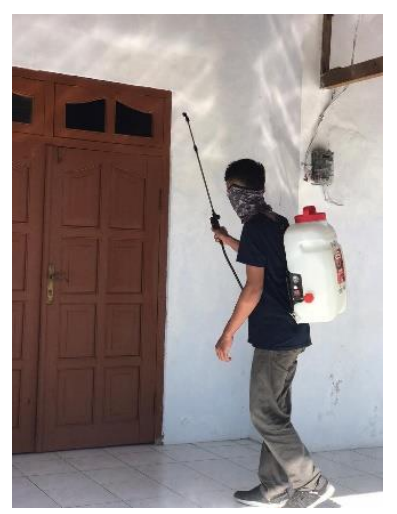

Source: author's personal document

Figure 2. RT 02 Spraying Activity

The picture above is a documentary of disinfecting spraying done by KKN UM in Kunti village on RT 02 . Disinfecting spraying is done outside and inside the house.

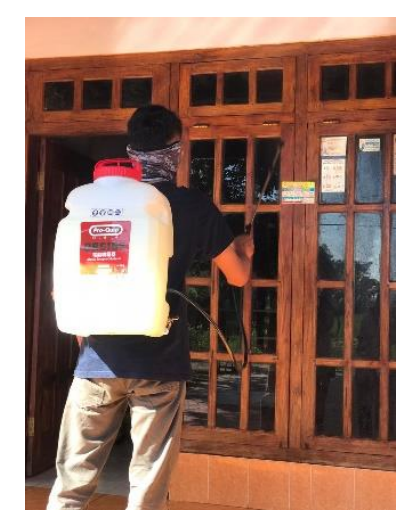

Source: author's personal document

Figure 3. RT 03 Spraying Activity

The picture above is a documentary of disinfecting spraying done by KKN UM in Kunti village on RT 03. Disinfecting spraying is done outside and inside the house. 


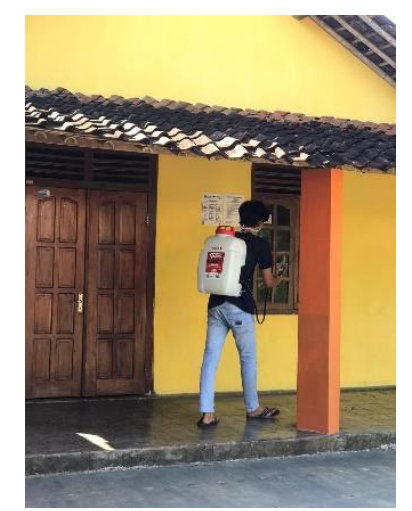

Source: author's personal document

Figure 4. RT 04 Spraying Activity

The picture above is a documentary of disinfecting spraying conducted by KKN UM in Kunti village on RT 04. Disinfecting spraying is done outside and inside the house.

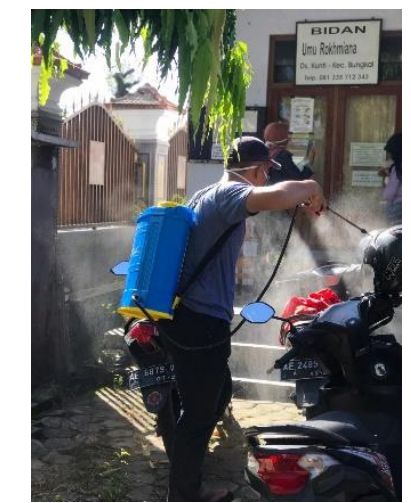

Source: author's personal document

Figure 5. Spraying activities at the Kunti Village Hall

The picture above is a documentation of disinfecting spraying done by KKN UM in Kunti Village Hall. Spraying dsinfektan carried out outside and inside the hall of the village.

\section{CONCLUSION}

With the completion of the Covid Edition KKN student work program in Kunti Village, Bungkal District, Ponorogo Regency, the translation of the Tri Dharma of Higher Education to the community can be carried out well. Through the implementation of this Community Service Program students can apply the knowledge gained during college in the form of community service in Kunti Village, Bungkal District, Ponorogo Regency in the form of disinfecting spraying activities that can reduce the spread of the corona virus. As an effort to prevent misunderstanding between residents and KKN students during disinfecting spraying, it is better to do more approaches between students and villagers considering that disinfecting spraying cannot be done by just one person and there is a group ban.

\section{REFERENCES}

Ali, MG, Ahmad, MO, \& Husain, SN (2020). Spread of Corona Virus Disease (COVID - 19) from an Outbreak to Pandemic in the Year 2020. Asian Journal of Research in Infectious Diseases, May, 37-51. https://doi.org/10.9734/ajrid/2020/v3i430135 
Dellanno, C., Vega, Q., \& Boesenberg, D. (2009). The antiviral action of common household disinfectants and antiseptics against murine hepatitis virus, a potential surrogate for SARS coronavirus. American Journal of Infection Control, 37 (8), 649-652. https://doi.org/10.1016/j.ajic.2009.03.012

Fatmah. (2006). Low Immune Response in Older Human Bodies. Makara Health, 10 (1), 47-53.

Hogue, BG, \& Machamer, CE (2014). Coronavirus Structural Proteins and Virus Assembly. Nidoviruses, 179-200. https://doi.org/10.1128/9781555815790.ch12

Kampf, G. (2020). Potential roles of inanimate surfaces for the spread of coronaviruses and their inactivation with disinfectant agents. Infection Prevention in Practice, 2 (2), 100044. https://doi.org/10.1016/j.infpip.2020.100044

RI Ministry of Health. (2020). Guidelines for the Prevention and Control of Coronavirus Disease (COVID19). Germas, 0-115.

Khan, S., Siddique, R., Ali, A., Bai, Q., Li, Z., Li, H., Shereen, MA, Xue, M., \& Prophet, G. (2020). The spread of Coronavirus novel has created an alarming situation worldwide. Journal of Infection and Public Health, 13 (4), 469-471. https://doi.org/10.1016/j.jiph.2020.03.005

Kumar, D. (2020). Corona Virus: A Review of COVID-19. Eurasian Journal of Medicine and Oncology, April. https://doi.org/10.14744/ejmo.2020.51418

Ong, SWX, Tan, YK, Chia, PY, Lee, TH, Ng, OT, Wong, MSY, \& Marimuthu, K. (2020). Water, Surface Environmental, and Personal Protective Equipment Contamination by Severe Acute Respiratory Syndrome Coronavirus 2 (SARS-CoV-2) from a Symptomatic Patient. JAMA - Journal of the American Medical Association, 323 (16), 1610-1612. https://doi.org/10.1001/ama.2020.3227

Shereen, MA, Khan, S., Kazmi, A., Bashir, N., \& Siddique, R. (2020). COVID-19 infection: Origin, transmission, and characteristics of human coronaviruses. Journal of Advanced Research, 24 (April), 91-98. https://doi.org/10.1016/j.jare.2020.03.005

Van Doremalen, N., Bushmaker, T., Morris, DH, Holbrook, MG, Gamble, A., Williamson, BN, Tamin, A., Harcourt, JL, Thornburg, NJ, Gerber, SI, Lloyd-Smith, JO , De Wit, E., \& Munster, VJ (2020). Aerosol and surface stability of SARS-CoV-2 as compared with SARS-CoV-1. New England Journal of Medicine, 382 (16), 1564-1567. https://doi.org/10.1056/NEJMc2004973

Wang, Z., Qiang, W., \& Ke, H. (2020). A Handbook of 2019-nCoV Pneumonia Control and Prevention. Hubei Science and Technology Press, 1-108. http://fpmpam.org/files/Handbook_2019nCoV.pdf

Yuliana (2020). Corona virus diseases (Covid -19); A literature review. Wellness and Healthy Magazine, 2 (1), 187-192. https://wellness.journalpress.id/wellness/article/view/v1i218wh 